\title{
HOW IMPORTANT IS APEC TO CHINA?
}

\section{YONGZHENG YANG \& YIPING HUANG}

China has actively participated in the APEC process since its inception in 1989. China seems to accept that APEC is important to its overall economic relations with the rest of the world. This judgment is not without empirical basis. The APEC region accounts for more than 60 per cent of China's trade, and a much higher percentage of its foreign capital inflows. However, China seems to have given a high profile to merchandise trade in the APEC process. This is manifested in President Jiang Zemin's announcement in the Osaka APEC summit in 1995 that China would slash its overall tariff level from 36 per cent to 23 per cent.

In making such a high profile and dramatic announcement, Jiang seemed to have China's WTO membership in his mind. China ultimately wants to enter the WTO, whose membership has strong implications for its trade (Anderson 1997a; Yang 1996). The announcement serves to demonstrate China's willingness to integrate with the world economy and to rally international support for its WTO bid. Whatever is on China's APEC agenda, there are questions. How important is APEC in its own right? How might China's participation in the APEC process help negotiations on its WTO membership?

Perhaps the most important question to ask is how APEC membership might help China in its domestic reform. Chinese negotiators have recently stressed the importance of WTO membership to domestic reform (Long 1998). After all, the long-term benefits of China's WTO membership to itself and the rest of the world are not going to come from China's free trade per se, but from its sustained growth. Further reform is essential to maintain the strong growth that China has achieved since it embarked on reform two decades ago.

There are significant differences in the nature of the institutions of the WTO and APEC and, thus, in the implications of their membership for China (Elek 1992; Anderson 1997b). While the WTO has binding rules of economic policies 
for its members, APEC relies largely on consensus and peer group pressure to achieve desired policy outcomes. Can APEC help facilitate China's reform to the same extent as the WTO?

In this chapter we first examine China's APEC strategy in relation to its WTO membership, economic diplomacy and overall economic reform. Particular emphasis is placed on the importance of the two institutions to the political economy of reform in China. We then evaluate the potential benefits of the proposed APEC trade liberalisation to China using a global general equilibrium model. These benefits are contrasted with those from hypothetical unilateral and global trade liberalisation in order to highlight the significance and limitations of the APEC initiative to China. Some sensitivity analysis is then undertaken to test the robustness of the simulation results and policy implications are drawn.

\section{CHINA'S APEC STRATEGY}

While APEC provides large potential for China's trade expansion, APEC's role in China's overall international economic relations goes far beyond this. APEC has become an important international forum for China to demonstrate its willingness to integrate with the world economy. APEC is made all the more important by the fact that China is not a member economy of the WTO, nor of the Organisation for Economic Cooperation and Development (OECD) (Garnaut and Huang 1995). As most of the APEC member countries are also economically the most important trade and investment partners for China, China can address important issues with its major economic partners in a more efficient and consistent way under the auspices of APEC. Bilateral negotiations are not only costly, but are also often seen as being discriminatory.

China wants to be perceived as a responsible member of the Asia Pacific community. By joining and participating in APEC, China reassures its smaller East Asian neighbours that it is committed to regional prosperity and stability. This is directly reflected in the announcement of the tariff reduction at the Osaka APEC Summit and the recent decision to maintain the yuan exchange rate in the wake of the Asian crisis despite strong economic pressure for devaluation.

China sees advantages of being an APEC member in dealing with the United States, especially in forming alliances with other East Asian member countries. China believes it is discriminated against by the United States. This belief is reenforced by the alleged reluctance of the United States to accelerate negotiations on China's WTO accession and the recent disputes between the two countries over the issue of intellectual property rights. China argues that violation of intellectual property rights is widespread in East Asia, and it resents being singled out on the issue by the United States. Such economic issues are intertwined with political issues, such as the disputes over human rights. Since many other 
Asian countries have a similar stand to China on trade and social issues, China feels more confident in dealing with the United States when it has support from its East Asian neighbours.

Perhaps central to China's APEC strategy is its intention to use APEC to build support for its WTO membership. By showing its commitment to the APEC region and its support for some of its East Asian neighbours over such issues as human rights and the proposed formation of the East Asian Economic Caucus, China is consolidating its support in the region. Bilateral talks on China's WTO accession with several key East Asian economies - most notably Japan and Korea-have made significant progress. China seems to have won more support for its WTO bid from its neighbours with a series announcements of the yuan exchange rate policy in the wake of the Asian currency crisis.

Finally, and perhaps most importantly, the APEC trade liberalisation process may help China's domestic reform. The Chinese leadership may not have set this as an explicit objective of its APEC agenda, but the impact will be significant if the APEC process succeeds. Officially, China gives its WTO membership great weight in helping domestic reform-also a bargaining chip (Long 1998). However, as WTO accession keeps eluding China, it may increasingly resort to APEC for external pressure for economic reform. Whether or not the Chinese government deliberately uses external pressure to push forward domestic reform, the APEC process will serve as a stimulus to trade liberalisation in China. In conforming with the commitments made by the Chinese government at the APEC Osaka meeting, China lowered its tariff rate for over 4,900 items on 1 April 1996 and the simple average tariff rate was brought down from 36 per cent to 23 per cent. On 1 October 1997, China further reduced its average tariff rate to 17 per cent, another significant drop of 26 per cent. In 1997, non-tariff measures on 17 items of products were eliminated. China will eliminate all nontariff barriers that are inconsistent with the WTO agreements by the end of 2010. China also advanced its commitment to the free convertibility of the Chinese currency for transactions in current accounts. The experiment on Chinese currency business by foreign banks is underway and nine foreign banks have been granted approval for it.

In its Individual Action Plan (IAP) submitted to APEC in October 1997, China made commitments for continued economic liberalisation in the near future. These include

- further reducing the average tariff rate to 15 per cent before the turn of the century

- increasing progressively the number of operational subsidiaries of foreign banks

- continuing and expanding the pilot programs of equity and contractual joint ventures in retail, wholesale and foreign trade businesses 
- opening 5 more cities - on top of the existing 12-for state-level joint ventures in tourism.

None of these reforms can be solely attributed to APEC. The pace of China's economic reform - and trade liberalisation in particular - is still largely determined by domestic political forces. Like in many other countries, a mercantilist approach to trade policy is pervasive in China. Although extremely high protection is now often regarded as protecting backwardness, 'moderate' protection is still widely considered necessary to protect indigenous industries. With growing open unemployment, it has become increasingly difficult politically for China to reduce its protection further. The willingness to liberalise unilaterally may come to a halt once China's overall tariff levels are comparable to those prevailing in other developing countries. Accession to the WTO should restore the process, but it is difficult to assess how fast China can move towards free trade from then on. If no substantial progress is made in the next round of WTO trade negotiations, then China's trade liberalisation process may begin to slow. If this happens, the APEC process would become even more important to China. The question is, can the APEC process continue to move forward rapidly if the WTO process is stalled?

China's past trade reform can largely be characterised as unilateral and it was one of the driving forces behind the economic success of the past two decades (Garnaut 1992; World Bank 1997). The impact of unilateral liberalisation can be significantly enhanced by similar liberalisation by China's trading partners (Yang 1996). Both APEC free trade and China's WTO accession can increase the prospects for continued export expansion. Despite the potentially substantial welfare gain from unilateral liberalisation, China feels more confident in opening its own market if it sees others are doing the same.

Irrespective of the prospects for APEC trade liberalisation, one should not overstate the stimulus effect or the external pressure that APEC can exert on China. In its approach to trade liberalisation, APEC opted for consensus and peer-group pressure (Drysdale and Garnaut 1992; Soesastro 1993). This seems to suit China's political need for flexibility in undertaking domestic reform in terms of timing and depth. However, this creates loopholes and reduces the disciplinary effect on domestic policy. Thus, APEC does not have the same effect on China's economic policy as the WTO may have, as the latter imposes binding rules on the policies of member countries. Both APEC and the WTO will help increase the transparency of China's trade regime, but the rules of the WTO and its trade policy review mechanism would probably exert greater pressure on China than the APEC harmonisation process.

In terms of geographical coverage, there is also a significant difference between APEC and the WTO. The WTO currently has more than 130 members, 
while APEC includes only 21 countries from the Asia Pacific region. While it may be cost-effective for China to negotiate on trade and investment issues with a smaller group of major trading partners within APEC, engaging other trading partners in the liberalisation process is also important. After all, nonAPEC economies account for nearly 40 per cent of China's trade. In addition, the WTO will provide a major forum for China to settle trade disputes with other countries once it becomes its member, although China may not be able to avoid potential discrimination against it, as some of these measures are likely to be incorporated in China's protocol of accession (Zhong and Yang 1998).

APEC is unable to address some important issues to China, especially in relation to the MFA and trade disputes. Despite its enormous importance to China and many other APEC economies, the MFA has not been a focus of APEC trade liberalisation. This is partly due to the Uruguay Round Agreement on Textiles and Clothing which will lead to the phasing out of MFA quotas by 2005 for WTO members. APEC free trade by 2010 for developed members cannot be of any help to China unless it is still outside the WTO by then. Recent trade disputes between China and several of its trading partners further demonstrate the inadequacy of the APEC process for China. Mexico, for example, recently imposed anti-dumping duties of 54-500 per cent on Chinese textiles and clothing. China had to rely entirely on bilateral efforts to deal with the problem as it is not a WTO member.

Disputes of a similar nature will probably be of increasing importance to China as its exports expand rapidly while its economy continues to be regarded as transitional. While the Uruguay Round has tightened the rules governing trade among WTO members, more discriminatory measures may be directed against China. A recent agreement between the United States and China, for example, stipulates that US quotas for Chinese textiles will continue well after the phasing out of the MFA.

As far as China is concerned, APEC cannot substitute for the WTO. APEC should be seen as both a forum for China to demonstrate its commitment to WTO rules and an opportunity to reform its trade regime. While APEC may provide an external environment conducive to trade liberalisation, it is the WTO that will serve as a more powerful force in ultimately placing China's economy under a rules-based trade regime. It is therefore in China's interests to continue to make efforts to join the WTO while pushing forward with unilateral liberalisation, both as a demonstration of its commitment to economic openness and as part of the APEC process. Such a strategy will not only prepare China for eventual WTO membership, but also bring economic benefits to China, and through cooperation with other APEC countries, overcome the resistance to domestic reform. 


\section{THE VALUE OF APEC}

In this section we employ a $9 \times 12$ (nine commodities and 12 regions) version of the GTAP model to evaluate the impact of APEC trade liberalisation on China. The model was implemented and solved using GEMPACK (Harrison and Pearson 1996). To capture the impact of APEC trade liberalisation, the world economy is first projected to the year 2005. We then assume that the full effect of the Uruguay Round reform takes place in 2005. As free trade in the APEC region will not occur until 2020, we further project the world economy to that year, assuming that by then the full impact of APEC liberalisation will be felt. The projected 2020 equilibrium of the world economy provides a benchmark for subsequent comparative static simulations of trade liberalisation.

The projections follow the methodology used in Hertel et al. (1996) and Yang et al. (1998). Essentially, forecasts of real GDP growth and primary factor accumulation are imposed on the world economy, and the implied (neutral) technological change - the difference between the growth of primary factors and real GDP - is deduced. Forecasts of major macroeconomic variables for various regions over the period 1992-2005 are obtained (Table 6.1). We base our projections of GDP growth and primary factor uses on Hertel et al. (1996) and the World Bank (1995). In light of the recent Asian crisis, the growth rates for the ASEAN, the newly industrialising economies (NIEs) and Japan are adjusted downward. Because only economy-wide GDP forecasts are available, only technological change at the economy-wide level can be deduced. It should be noted, however, that sectoral GDP does not grow at the same rate in the projection even though only the economy-wide GDP growth rate is projected. Because of variations in factor intensity among sectors, different rates of factor accumulation mean that sectoral growth will differ among sectors-the Rybczynski effect. In addition, consumer preferences are non-homothetic, so that the growth of demand for various products differs as income rises.

In the projection, all prices and sectoral quantities endogenously adjust to exogenous changes in macroeconomic variables. Labour and capital are perfectly mobile across sectors while land is partially mobile. Regional savings are a fixed proportion of income and are pooled together in a 'global bank'. Global savings are allocated to investment in such a way that each region retains its share in global investment. This effectively constrains large changes in the trade balance. No policy change is implemented in the projection from 1992 to 2005. Based on the evidence provided by Gehlhar (1997), the trade elasticities in the GTAP model are doubled in the projection and subsequent comparative static simulations. Gehlhar found that structural changes in the Asia Pacific economies over time would be best replicated if the trade elasticities are doubled. Full details of the GTAP elasticities and other data can be found in McDougall (1997). 
Table 6.1 Projected annual average growth of macroeconomic variables, 1992-2005 (per cent)

\begin{tabular}{|c|c|c|c|c|}
\hline & Population & Labour & Capital & Real GDP \\
\hline Australasia & 0.7 & 0.6 & 2.1 & 2.5 \\
\hline North America & 0.7 & 0.9 & 2.8 & 2.7 \\
\hline EU-12 & 0.2 & 0.2 & 1.3 & 2.2 \\
\hline Japan & 0.3 & -0.2 & 2.5 & 2.0 \\
\hline NIEs & 0.9 & 0.9 & 5.0 & 5.0 \\
\hline ASEAN & 1.6 & 2.2 & 6.0 & 6.0 \\
\hline China & 1.3 & 2.4 & 9.3 & 8.9 \\
\hline South Asia & 1.8 & 2.4 & 7.1 & 5.2 \\
\hline Latin America & 1.7 & 2.2 & 1.2 & 3.6 \\
\hline Central and Eastern Europe & 0.9 & 0.9 & 6.0 & 6.0 \\
\hline Former Soviet Union & 0.0 & 0.0 & 4.4 & 4.4 \\
\hline Rest of the world & 1.3 & 2.4 & 2.5 & 2.5 \\
\hline
\end{tabular}

The post-Uruguay Round equilibrium of the world economy in 2005 is created by simulating the Uruguay Round reforms at the projected baseline in 2005 . Following Yang et al. (1998), our estimates of tariff cuts and agricultural liberalisation are based on GATT $(1993,1994)$ and UNCTAD (1995). Essentially, domestic support for agriculture is reduced by 20 per cent, and export subsidies and tariffs (including their equivalents of quantitative restrictions) by 36 per cent. Tariffs on textiles and clothing are reduced by 18 per cent in North America, 16 per cent in the European Union (EU) (15 per cent for imports from developing economies), and 33 per cent in Japan. For developing countries, domestic support for agriculture is cut by 15 per cent, export subsidies by 24 per cent, and tariffs by 26 per cent. Tariff reductions in developing countries are two-thirds of that in industrial countries.

Once the Uruguay Round trade liberalisation is carried out, the world economy is projected to 2020 , following the same procedures as those used for the projection to 2005 . The projection was made from the 2005 post-Uruguay Round database by accumulating factors of production and increasing real GDP across the regions consistent with the forecasts. In most cases, trend forecasts for the period 1992-2005 are extrapolated to the year 2020. In the case of China, we have projected a slowing down of GDP growth for the period 2005-2020 (to 7.3 per cent per year). Unlike in the period 1992-2005-when the labour force grows much more rapidly than population-we have assumed that over the period 2006-2020, labour force growth is the sum of population growth, which is based on the SSB (1996) projection, and any unemployment left over from 
the period 1992-2005 (Yang and Zhong 1998). Again, no policy changes are incorporated in the projection.

The same model closure is used in the Uruguay Round reform experiment for the year 2005 and all other comparative static simulations for 2020 . This closure is similar to the one used in the projections. In the comparative static experiments, however, land, labour, capital stock and technology are all fixed. Unlike dynamic models, such as the G-Cubed model (McKibbin and Wilcoxen 1995) and the Monash model (Dixon and Rimmer 1997), GTAP is a one-period model. Investment therefore does not augment capital stock in the next period, although it affects final demand in the current period.

Two scenarios are postulated for APEC trade liberalisation. In the first scenario, all border barriers to trade in the APEC economies, including those to agricultural trade, are eliminated on a MFN basis. On the import side, these barriers include tariffs, quotas, variable import levies and any other import restrictions, such as anti-dumping duties. On the export side, export subsidies, taxes and MFA quotas (which are modelled as export taxes) are abolished altogether. Output subsidies are also removed. In the second scenario, we assume that distortions in agriculture are retained while all those in other sectors are eliminated as in the first scenario. This scenario is intended to highlight the importance of agricultural liberalisation in the APEC process. To put in perspective the potential benefits to China of concerted MFN trade liberalisation in the APEC region, a third experiment on unilateral MFN trade liberalisation by China was also undertaken. In this scenario, China eliminates all its trade distortions without any other countries reciprocating. The results for these three scenarios are reported in Table 6.2 .

Under the scenario of comprehensive APEC trade liberalisation, China's real GDP increases by nearly 3 per cent (column 1 of Table 6.2). This large expansion of domestic production reflects the extent of trade distortions in China. Measured in equivalent variation, however, the welfare gain to China is not as significant as the increase in domestic production suggests. The US $\$ 23.9$ billion welfare gain is equivalent to only 0.6 per cent of GDP in 2020 . The discrepancy between production expansion and welfare gain results from a substantial decline (4.1 per cent) in China's terms of trade following APEC trade liberalisation. Decomposition of the welfare effect shows that the deterioration of the terms of trade translates to a US $\$ 74.4$ billion welfare loss. The massive efficiency gain from trade liberalisation, however, more than compensates for this loss. Further decomposition of the allocative efficiency gain indicates that the massive expansion of imports is largely responsible for the higher efficiency, although export expansion also contributes significantly. This suggests that it is China's own liberalisation that is most important for its welfare position in the APEC process. Both exports and imports expand substantially, but the latter expand 
Table 6.2 The impact on China of APEC and unilateral trade liberalisation, 2020

\begin{tabular}{lccc}
\hline & $\begin{array}{c}\text { Comprehensive } \\
\text { APEC }\end{array}$ & $\begin{array}{c}\text { APEC excluding } \\
\text { agriculture }\end{array}$ & $\begin{array}{c}\text { Unilateral trade } \\
\text { liberalisation }\end{array}$ \\
\hline Equivalent variation (US\$b) & 23.9 & 16.3 & 17.2 \\
Allocative efficiency & 98.3 & 92.4 & 98.9 \\
Terms of trade effect & -74.4 & -76.1 & -81.7 \\
Real GDP (per cent) & 2.9 & 2.7 & 2.9 \\
Terms of trade (per cent) & -4.1 & -4.2 & -4.5 \\
Real exports (per cent) & 41.8 & 41.3 & 41.1 \\
Real imports (per cent) & 70.3 & 69.4 & 68.1 \\
Trade balance (US\$b) & -20.1 & -20.7 & -21.2
\end{tabular}

Source: Simulations of the GTAP model, database version 3.

more than the former, leading to a US $\$ 20$ billion reduction in China's trade surplus in 2020 .

If agriculture is excluded from APEC trade liberalisation, the increase in China's GDP is only slightly lower, but the overall welfare gain to China-as measured by equivalent variation - is reduced by nearly one-third (column 2 of Table 6.2). Not only is the efficiency gain smaller, but the adverse terms of trade effect also becomes larger. The terms of trade further deteriorate despite the fact that both exports and imports expand less if agriculture is excluded from APEC trade liberalisation. China has moderate levels of agricultural protection compared to many other economies in the APEC region. When agriculture is liberalised, the terms of trade for China's agricultural sector improve as export demand rises.

Judging by the welfare effects, APEC trade liberalisation without agriculture would be a less desirable option for China than unilateral trade liberalisation. As shown in the last column of Table 6.2, the large efficiency gain from unilateral trade liberalisation more than compensates for the increased terms of trade loss. Real GDP growth is also higher under unilateral trade liberalisation than under APEC without agriculture. Comparison of the results between full APEC and unilateral trade liberalisation shows that the main benefits to China from the APEC process come from the terms of trade effect. Simultaneous liberalisation by other countries increases China's welfare by over US\$7 billion.

The most noticeable effect of full APEC liberalisation on different sectors is observed in the food processing industry, which has been highly protected by tariffs. The removal of tariffs leads to substantial contraction of this industry, in turn weakening demand for crops and livestock products. As a result, production 
in the two industries also falls. Combined with strong export demand from other APEC economies - especially Japan, the NIEs and North America-lower domestic prices lead to a surge in agricultural exports, albeit from a small base (projected agricultural exports in 2020 are quite small) (Table 6.4). Crop imports, on the other hand, decline because of the removal of import subsidies, while imports of livestock products increase moderately with the elimination of tariffs (Table 6.5).

Output in the clothing industry also expands, despite the removal of the high tariff for the industry. This results largely from the removal of MFA quotas and

Table 6.3 The impact on China's production of APEC and unilateral trade liberalisation, 2020 (per cent)

\begin{tabular}{lccc}
\hline & $\begin{array}{c}\text { Comprehensive } \\
\text { APEC }\end{array}$ & $\begin{array}{c}\text { APEC excluding } \\
\text { agriculture }\end{array}$ & $\begin{array}{c}\text { Unilateral trade } \\
\text { liberalisation }\end{array}$ \\
\hline Crops & -5.2 & -6.7 & -6.7 \\
Livestock products & -0.7 & 3.1 & 1.7 \\
Natural resources & -6.5 & -7.5 & -9.1 \\
Processed food & -50.2 & -41.4 & -41.2 \\
Textiles & -27.4 & -21.0 & -27.0 \\
Clothing & 44.2 & 45.3 & 43.9 \\
Automobiles and equipment & 6.4 & 5.0 & 7.5 \\
Basic manufactures & -1.3 & -1.8 & -3.7 \\
Services & 0.5 & 0.5 & 0.6
\end{tabular}

Source: Simulations of the GTAP model, database version 3.

Table 6.4 The impact on China's exports of APEC and unilateral trade liberalisation, 2020 (per cent)

\begin{tabular}{lccc}
\hline & $\begin{array}{c}\text { Comprehensive } \\
\text { APEC }\end{array}$ & $\begin{array}{c}\text { APEC excluding } \\
\text { agriculture }\end{array}$ & $\begin{array}{c}\text { Unilateral trade } \\
\text { liberalisation }\end{array}$ \\
Crops & 135.8 & 26.5 & 41.0 \\
Livestock products & 148.9 & 15.3 & 27.7 \\
Natural resources & 23.7 & 18.4 & 8.0 \\
Processed food & -13.2 & 67.4 & 35.7 \\
Textiles & 79.1 & 94.4 & 71.9 \\
Clothing & 79.4 & 81.3 & 81.4 \\
Automobiles and equipment & 33.5 & 31.8 & 35.3 \\
Basic manufactures & 38.9 & 38.7 & 25.0 \\
Services & 9.7 & 8.6 & 11.1
\end{tabular}

Source: Simulations of the GTAP model, database version 3. 
Table 6.5 The impact on China's imports of APEC and unilateral trade liberalisation, 2020 (per cent)

\begin{tabular}{lrcc}
\hline & $\begin{array}{c}\text { Comprehensive } \\
\text { APEC }\end{array}$ & $\begin{array}{c}\text { APEC excluding } \\
\text { agriculture }\end{array}$ & $\begin{array}{c}\text { Unilateral trade } \\
\text { liberalisation }\end{array}$ \\
\hline Crops & -37.9 & -20.2 & -23.8 \\
Livestock products & 4.4 & -2.6 & -2.4 \\
Natural resources & 13.2 & 14.6 & 16.2 \\
Processed food & 509.6 & 410.1 & 400.0 \\
Textiles & 143.8 & 140.0 & 136.2 \\
Clothing & 1349.5 & 1358.5 & 1332.2 \\
Automobiles and equipment & 148.5 & 149.5 & 149.4 \\
Basic manufactures & 53.8 & 54.0 & 53.5 \\
Services & -3.6 & -3.2 & -4.5 \\
& & &
\end{tabular}

Source: Simulations of the GTAP model, database version 3.

relatively high tariffs (compared with other manufactures) imposed by North America and Japan. In addition, the removal of tariffs on textiles significantly reduces the input costs for clothing production. Nevertheless, the strong demand from the clothing industry fails to prevent a decline in the output of the textile industry. The elimination of high tariffs on textiles does improve the competitiveness of Chinese textiles in overseas markets. Together with the removal of MFA quotas and tariffs in other APEC economies, this leads to considerable expansion of textile exports.

Imports of clothing increase dramatically following the elimination of high tariffs. It should be noted, however, that this occurs from a very small base as China has a strong comparative advantage in clothing production and most of the high tariffs on clothing products are probably redundant. The simulation result on clothing imports is therefore likely to be biased upward.

The automobile and equipment industry expands following APEC liberalisation, but basic manufactures suffer a small contraction. The service sector expands slightly as its internal terms of trade improves. Despite the widespread negative impact on production after APEC trade liberalisation, trade (imports plus exports) expands for virtually all commodities, although exports of processed food and imports of crops and services decline marginally. This shows that under the assumption of differentiated products, exports and imports can expand simultaneously with APEC trade liberalisation, leading to a more open Chinese economy in the process. It is this openness that improves the overall efficiency of resource allocation in the Chinese economy. 
Excluding agriculture from the APEC trade liberalisation scenarios has little impact on sectoral output, but the outcome for agricultural exports is drastically different in the scenario of APEC without agriculture. Instead of massive expansion, agricultural exports increase only moderately, more slowly than the exports of most other commodities. With import subsidies retained, imports of crops fall less. Without tariff reductions, imports of livestock products decline, while they increase in the case of full APEC liberalisation.

Sectoral results under unilateral trade liberalisation are very similar to those under APEC trade liberalisation without agriculture. Agricultural exports do expand more with unilateral trade liberalisation, as other exports expand less when there are no increases in demand from other APEC economies. Imports of crops, on the other hand, fall even more strongly.

Caution is warranted in interpreting the sectoral results presented in the tables. The GTAP database includes perhaps the most comprehensive trade distortion data that one can find in any global model. China's protection data, however, leaves much to be desired, as it does in virtually all models. Extensive non-tariff barriers in the Chinese trade regime are hardly covered in the GTAP database. Thus, trade liberalisation implemented for China in the above simulations represents at best, tariff reductions. Without the removal of non-tariff barriers-especially quantitative restrictions-estimates of sectoral results can be biased, as can welfare results. In addition, there are great variations in the tariff levels among commodities. This tends to lead to greater welfare losses than under uniform tariffs of the same average level. Offsetting these biases are the extensive tariff exemptions and rebates mentioned earlier. It is difficult to evaluate the net effect of these factors. One such an attempt has been made by Bach et al. (1996).

Aggregation may also lead to biases in sectoral results, and this can result in difficulties in the interpretation of results. For example, the basic manufactures industry includes a lager number of sub-industries with a wide range of factor intensity and protection levels. The automobile industry would probably have contracted had it been separated out from the more aggregate automobile and equipment industry. To obtain more accurate sectoral results, a more disaggregated database is desired, but this needs to be balanced against the increased complexity of results and computing requirements.

How important is APEC and unilateral trade liberalisation compared to the global trade liberalisation that the WTO aims to achieve? By global trade liberalisation, we mean that all countries undertake to eliminate all their trade distortions, including tariffs, non-tariff barriers, export subsidies and taxes, and domestic support for agriculture. The results of global trade liberalisation are reported in the first column of Table 6.6. In the next three columns, the results for the previous three scenarios are reported as percentages of the outcomes of global trade liberalisation. As expected, welfare benefits to China from global 
Table 6.6 APEC and unilateral trade liberalisation versus global trade liberalisation, 2020

\begin{tabular}{lcccc}
\hline & \multicolumn{3}{c}{ As per cent of global trade liberalisation } \\
& $\begin{array}{c}\text { Global trade } \\
\text { liberalisation }\end{array}$ & APEC & agriculture & $\begin{array}{c}\text { Unilateral } \\
\text { trade } \\
\text { liberalisation }\end{array}$ \\
& & & & 37.3 \\
Equivalent variation (US\$b) & 43.7 & 54.6 & 39.3 \\
Allocative efficiency & 99.8 & 98.5 & 92.6 & 99.1 \\
Terms of trade effect & -56.1 & 132.6 & 135.7 & 145.6 \\
Real GDP (per cent) & 2.9 & 100.0 & 93.1 & 100.0 \\
Terms of trade (per cent) & -3.1 & 134.1 & 136.7 & 146.9 \\
Real exports (per cent) & 43.6 & 95.9 & 94.7 & 94.3 \\
Real imports (per cent) & 74.0 & 95.0 & 93.8 & 92.0 \\
Trade balance (US\$b) & -8.1 & 248.7 & 256.4 & 262.1 \\
Source: Simulations of the GTAP model, database version 3. & & \\
\hline
\end{tabular}

trade liberalisation are larger than from both APEC and China's unilateral trade liberalisation. A comprehensive APEC program would generate 55 per cent of what China would gain from global trade liberalisation, and APEC liberalisation without agriculture would give China 37 per cent of its potential benefits from global trade liberalisation. Unilateral trade liberalisation scores slightly better than APEC without agriculture as far as welfare impact on China is concerned. As in the case of the comparison between full APEC and unilateral trade liberalisation, the larger gain from global trade liberalisation is primarily a result of the improved terms of trade for China, although in comparison with APEC liberalisation excluding agriculture, efficiency gains are important as well. The improvement in China's terms of trade is more or less proportional to the regional coverage of trade liberalisation. The non-APEC region accounts for about 38 per cent of China's total trade. Trade liberalisation in these countries reduces the adverse terms of trade effect of APEC on China by about one-third.

Under global trade liberalisation, China's GDP increases to a similar extent to that in the three previous scenarios. The greatest difference between global liberalisation on the one hand, and APEC and unilateral liberalisation on the other, occurs in the trade balance. In the simulations, we allowed the trade balance to adjust. Despite similar trade expansion, APEC and unilateral trade liberalisation lead to a reduction in the trade surplus one-and-a-half times larger than global trade liberalisation. The much more favourable export prices under global trade liberalisation explain a large part of the difference. China has a large current account surplus in the base year. Reductions in the trade surplus do not pose a balance of payments problem. 


\section{SENSITTVITYANALYSIS}

Simulation results in the previous section show that China suffers large terms of trade losses from trade liberalisation despite overall welfare gains. It is well known that in the Armington-type demand systems, such terms of trade losses are related to the elasticity of substitution among sources of supply as well as country size. In this section, we test the sensitivity of the simulation results to two sets of elasticities: the elasticities of substitution between domestic goods and imports, and those between various sources of imports. We first halve these elasticities across all commodities and then double them. Other possible variations in the elasticities are not cosidered here because of the excessive computing resources they would require.

The welfare results of trade liberalisation are sensitive to the magnitude of the elasticities of substitution (Table 6.7). With lower elasticities, China loses in every scenario except global trade liberalisation. In contrast, higher elasticities lead to large welfare gains in every scenario, and these gains are several times those in the central scenarios of the previous section. When the elasticities are lower, not only are the negative terms of trade effects larger, but the allocative efficiency gains are smaller. In fact, it is the decline in allocative efficiency gains that is mainly to blame for China's welfare losses. The results for the higher elasticity scenario confirm this. Thus, while the terms of trade effects vary considerably between the lower and higher elasticity scenarios, differences in allocative efficiency largely determine the overall welfare results.

Table 6.7 The impact of trade liberalisation on China: sensitivity analysis; 2020

\begin{tabular}{lrrrrrrrrr}
\hline & \multicolumn{2}{c}{$\begin{array}{c}\text { Unilateral trade } \\
\text { liberalisation }\end{array}$} & \multicolumn{2}{c}{$\begin{array}{c}\text { Compre- } \\
\text { hensive APEC }\end{array}$} & $\begin{array}{c}\text { APEC excluding } \\
\text { agriculture }\end{array}$ & $\begin{array}{c}\text { Global trade } \\
\text { liberalisation }\end{array}$ \\
Elasticity of substitution $=>$ & Low & High & Low & High & Low & High & Low & High \\
Equivalent variation (US\$b) & -25.5 & 115.3 & -20.5 & 112.7 & -19.8 & 98.3 & 0.7 & 125.1 \\
$\quad$ Allocative efficiency & 45.2 & 212.1 & 47.5 & 183.9 & 42.6 & 191.0 & 47.9 & 182.2 \\
$\quad$ Terms of trade effect & -70.7 & -96.8 & -68.0 & -71.2 & -62.4 & -92.7 & -47.2 & -57.1 \\
Real GDP (per cent) & 1.3 & 6.2 & 1.3 & 5.5 & 1.2 & 5.6 & 1.3 & 5.4 \\
Terms of trade (per cent) & -4.2 & -4.6 & -4.1 & -3.4 & -3.7 & -4.4 & -2.8 & -2.7 \\
Real exports (per cent) & 18.8 & 84.0 & 19.0 & 87.0 & 19.0 & 82.7 & 19.8 & 87.8 \\
Real imports (per cent) & 29.3 & 143 & 29.3 & 153.6 & 30.5 & 142.1 & 31.2 & 155.4 \\
Trade balance (US\$b) & -25.4 & -6.9 & -21.4 & -12.0 & -22.8 & -11.0 & -7.9 & -2.4
\end{tabular}

Source: Simulations of the GTAP model, database version 3. 
These sensitivity results must be interpreted with caution. If the elasticities of substitution were indeed as low as in our lower elasticity scenario, it is possible that China has nothing to gain from APEC trade liberalisation as far as its static effects are concerned. As discussed earlier, however, the value of APEC to China is not merely a one-off increase in allocative efficiency. Although this static gain is important, the largest benefits of APEC are probably from its facilitation of domestic reform and China's WTO accession. The simulation results show that China is more likely to benefit from multilateral trade liberalisation under the auspice of the WTO (even with lower elasticities). This is not surprising, as by 2020 China is so large that its own trade liberalisation can exert considerable negative terms of trade effects on itself. Multilateral liberalisation is most effective in mitigating the terms of trade effect.

It should also be borne in mind that our simulation results tend to underestimate the welfare gains of trade liberalisation. Simulations using models incorporating economies of scale and imperfect competition generally show larger welfare benefits of trade liberalisation (Francois et al. 1997; Harrison et al. 1996). Despite its large domestic market, China has not been able to exploit economies of scale for its industries, nor has it been able to improve competition substantially in many key industries, such as telecommunications and banking (Cao 1993; He and Yang 1998). One would expect that welfare gains from the exploitation of these economies of scale and increased competition in China are large.

\section{CONCLUSION}

APEC seems to be an imperative for China's economic diplomacy. Having been denied earlier accession to the WTO, China sees APEC as an important forum to show its commitment to economic openness and to demonstrate the importance that China attaches to its neighbours. Concerted liberalisation in the APEC region reduces the adverse terms of trade effect of China's own trade liberalisation. All these help to maintain the momentum of reform by reducing domestic resistance. APEC is not a stepping stone to WTO membership, but it gives China an opportunity to rally international support for its early entry into the WTO.

To build a more open, rules-based economy, China must continue to seek early entry to the WTO. This is not only because the WTO framework provides greater security for market access for Chinese exports and potentially larger gains to the Chinese economy, but also because it imposes legal bindings on China's trade policy once it becomes a member.

In facilitating China's trade liberalisation, APEC and the WTO seem to be mutually re-inforcing. APEC prepares China for the WTO and the WTO accession pushes China to go along with the APEC process. Both APEC and WTO accession propel domestic reform. At a critical time of state enterprise 
reform, it is important to lock China's domestic reform into a process of economic integration with the rest of the world. While such a process cannot replace hard work in fostering domestic support for further reform, it helps reform both by providing tangible economic benefits and by encouraging rules-based institutions.

\section{APPENDIXA \\ REGIONAND COMMODITYDESCRIPTIONS}

\section{Table A6.1 Region descriptions}

\begin{tabular}{ll}
\hline Region & GTAP region descriptions \\
Australasia & Australia and New Zealand \\
North America & United States and Canada \\
EU-12 & 12 member states \\
Japan & Japan \\
NIEs & Hong Kong, Republic of Korea, Singapore and Taiwan \\
ASEAN & Indonesia, Malaysia, the Philippines and Thailand \\
China & China \\
South Asia & Bangladesh, Pakistan, India, Sri Lanka, and rest of South Asia \\
Latin America & Mexico, Central America and the Caribbean, Argentina, Brazil, \\
Chile, rest of South & \\
America & \\
Central and Eastern & \\
European Associates & Poland, Hungary, Czech Republic, Slovakia, Romania, Bulgaria \\
Former Soviet Union & Former Soviet Union \\
Rest of the world & Regions not included above \\
\end{tabular}

Table A6.2 Commodity descriptions

\begin{tabular}{ll}
\hline Commodity & GTAP commodity descriptions \\
Crops & Paddy rice, wheat, other grains, non-grain crops and \\
& processed rice \\
Livestock products & Wool, other livestock, meat products, and milk products \\
Natural resources & Forestry, fishery, coal, oil, gas, and other minerals \\
Processed food & Other food products, and beverages \& tobacco \\
Textiles & Textiles and leather products \\
Clothing & Clothing \\
Machinery and & Transport equipment, machinery and equipment, other \\
equipment & manufactures \\
Basic manufactures & Lumber, pulp \& paper etc., petroleum \& coal, chemicals rubber \\
& \& plastics, non-metallic minerals, primary ferrous metals, non- \\
& ferrous metals, and fabricated metal products \\
Services & Electricity water \& gas, construction, trade \& transport, other \\
& services (private), other services (government), and ownership \\
& of dwellings
\end{tabular}




\section{APPENDIX B \\ TRADE ELASTICITIES}

Table B6.1 Central scenario trade elasticities used in this study

\begin{tabular}{lcc}
\hline & $\begin{array}{c}\text { Elasticities of substitution } \\
\text { between imports and } \\
\text { domestic products }\end{array}$ & $\begin{array}{c}\text { Elasticities of substitution } \\
\text { among imports by } \\
\text { place of production }\end{array}$ \\
\hline Crops & 4.4 & 8.8 \\
Livestock products & 4.9 & 9.3 \\
Natural resources & 5.6 & 11.2 \\
Processed food & 5.0 & 9.9 \\
Textiles & 5.3 & 11.6 \\
Clothing & 8.8 & 17.6 \\
Machinery \& equipment & 7.1 & 13.7 \\
Basic manufactures & 4.5 & 9.0 \\
Services & 3.9 & 7.6 \\
\end{tabular}

\section{REFERENCES}

Anderson, K., 1997a. 'On the complexities of China's WTO accession', The World Economy, 20:749-72.

(ed.), 1997b. Strengthening the Global Trading System: from GATT to WTO, Centre for International Economic Studies, University of Adelaide, Adelaide.

Bach, C.F., Martin, W. and Stevens, J., 1996. 'China and the WTO: tariff offers, exemptions, and welfare implications', Weltwirtschaftliches Archiv, 132:40931.

Bergsten, C.F., 1994. 'APEC and the world economy: a force for worldwide liberalisation', Foreign Affairs, 73:20-6.

Cao, Y., 1993. The Chinese iron and steel industry in transition: towards market mechanisms and economic efficiency, $\mathrm{PhD}$ dissertation, The Australian National University, Canberra.

Dixon, P.B. and Rimmer, M.T., 1997. Monash: a disaggregated, dynamic model of the Australian economy, Centre of Policy Studies and Impact Project, Monash Univesity, Melbourne. (mimeo)

Drysdale, P. and Garnaut, R., 1992. 'The Pacific: an application of a general theory of economic integration', in C.F. Bergsten and M. Noland (eds), 
Pacific Dynamism and the International Economic System, Institute for International Economics, Washington, DC.

Elek, A., 1992. 'Trade policy options for the Asia Pacific region in the 1990s: the potential of open regionalism', American Economic Review, 82:74-8.

Francois, J.F., McDonald, B. and Nordstrom, H., 1997. 'The Uruguay Round: a global general equilibrium assessment', in D. Robertson (ed.), East Asian Trade after the Uruguay Round, Cambridge University Press, Cambridge. Garnaut, R., 1992. 'China's reforms in international context', in R. Garnaut and G. Liu (eds), Economic Reform and Internationalisation, Allen \& Unwin, Sydney, in association with the Pacific Trade and Development Conference Secretariat, The Australian National University.

- _ and Huang, Y., 1995. 'Trade liberalisation and transition in China: opportunities and challenges for OECD countries', report prepared for the Trade Directorate, OECD, Paris.

General Agreement on Tariffs and Trade (GATT), 1993. An Analysis of the Proposed Uruguay Round Agreement, with Particular Emphasis on Aspects of Interest to Developing Economies, Geneva, 29 November.

- 1994. News of the Unuguay Round of Multilateral Trade Negotiations, April, Geneva.

Gehlhar, M., 1997. 'Historical analysis of growth and trade patterns in the Pacific Rim: an evaluation of the GTAP framework', in T. Hertel (ed.), Global Trade Analysis Using the GTAP Model, Cambridge University Press, Cambridge.

Harrison, G.W., Rutherford, T.F. and Tarr, D., 1996. 'Quantifying the Uruguay Round', in W. Martin and A.L. Winters (eds), The Uruguay Round and the Developing Countries, Cambridge University Press, Cambridge.

Harrison, W.J. and Pearson, K.R., 1996. 'Computing solutions for large general equilibrium models using GEMPACK', Computational Economics, 9:83-127.

He, J.M. and Yang, Y., 1998. 'The political economy of trade liberalisation in China', National Centre for Development Studies, The Australian National University, mimeo.

Hertel, T. (ed.), 1997. Global Trade Analysis: modeling and applications, Cambridge University Press, Cambridge.

- Martin, W., Yanagishma, K. and Dimaranan, B., 1996. 'Liberalising manufactures trade in a changing world economy', in W. Martin and A.L. Winters (eds), The Uruguay Round and the Developing Countries, Cambridge University Press, Cambridge. 
Huff, K.M. and Hertel, T.W., 1996. Decomposing Welfare Change in the GTAP Model, GTAP Technical Paper No. 5, Center for Global Trade Analysis, Purdue University, Western Lafayette.

Long, Y., 1998. 'China's integration into the world economy: challenges from the new global prosperity', presentation made at the international conference 'China's Integration into the Global Economy', 17 January 1998, Harvard University, Cambridge.

McDougall, R.A. (ed.), 1997. Global Trade, Assistance, and Protection: the GTAP 3 Data Base, Centre for Global Trade Analysis, Purdue University, West Lafayette.

McKibbin, W.J. and Wilcoxen, P.J., 1995. The theoretical and empirical structure of the G-Cubed model, Brookings Discussion Papers in International Economics, No. 118, Brookings Institute, Washington, DC.

Soesastro, H., 1993. 'Pacific economic cooperation: the history of an idea', in B.K. Bundy, K. Weichel and S.D. Burns (eds), The Future of Regional Cooperation in the Pacific Rim, Center for the Pacific Rim, University of San Francisco.

State Statistical Bureau (SSB), 1994. Kua shiji de zhongguo renkou (China's population into the next century), China Statistical Publishing House, Beijing.

UNCTAD, 1995. An Analysis of Trading Opportunities Resulting from the Uruguay Round in Selected Sectors: agriculture, textiles and clothing, and other industrial products, UNCTAD, Geneva.

World Bank, 1995. Global Economic Prospects and the Developing Countries, World Bank, Washington, DC.

1997. 'China engaged: integration with the global economy', China 2020 Series, World Bank, Washington, DC.

Yang, Y., 1996. 'China's WTO membership: what's at stake?', The World Economy, 19:661-82.

and Zhong, C., 1998. 'China's textile and clothing exports in a changing world economy', The Developing Economies, XXXVI:3-23.

Yang, Y., Duncan, R.C. and Lawson, T., 1998. 'Trade liberalisation in the European Union and APEC: what if the approaches were exchanged?', in P. Drysdale and D. Vines (eds), Europe, East Asia and APEC: a shared global agenda?, Cambridge University Press, Cambridge.

Zhong, C. and Yang, Y., 1998. 'China's textile and clothing exports in the postUruguay Round', in P. Drysdale and L.G. Song (eds), China's Entry into the WTO: issues and quantitative assessments, Routledge. 


\section{NOTES}

This is a modified version of an article that appeared in The Australian Economic Papers, September 1999. (reproduced with permission here)

The authors are grateful for comments and suggestions made by the anonymous referee and the participants at the International Conference $A P E C$

and its Impact on the Chinese Economy, held at The Australian National University, Canberra, 16 February 1998. 